\title{
Neuroprotective and Anti-Inflammatory Properties from the Bioactive Constituents of Myracrodruon Urundeuva, a Brazilian Medicinal Species
}

\author{
Glauce Socorro de Barros Viana ${ }^{1 *}$ and lana Bantim Felício Calou ${ }^{2}$ \\ ${ }^{1}$ Faculty of Medicine, Federal University of Ceará, Fortaleza, Brazil \\ ${ }^{2}$ Federal University of Piauí, Picos, Brazil
}

\begin{abstract}
Myracrodruon urundeuva Fr. All. (Anacardiaceae) is largely used, by the Northeast Brazil population, for its antiinflammatory actions, already confirmed by experimental studies. In addition, this medicinal species presents neuroprotective properties, as demonstrated by in vitro and in vivo Parkinson's disease models. The trunk bark of $M$. urundeuva is a rich source of bioactive polyphenol compounds, as tannins and chalcones considered precursors of flavonoid biosynthesis. Not only the standardized plant extract, but also its isolated compounds present analgesic and anti-inflammatory effects, observed in acute models of nociception and inflammation in rodents. Besides, due to their anti-inflammatory and antioxidant activities, chalcones drastically inhibit myeloperoxidase (MPO) activity and have been effective in an allergic conjunctivitis model. Possibly, all these effects of $M$. urundeuva are involved with the neuroprotection offered by the standardized extract, SEMU (rich in chalcones), and isolated compounds, in rat mesencephalic cells exposed to 6-OHDA and in the classical hemiparkinsonian model of Parkinson's disease induced by 6-OHDA in rats. We showed that the standardized extract reverted behavioral (apomorphine-induced contralateral rotations) and neurochemical alterations (striatal monoamine concentrations, as well as DAT and TH immunostainings) observed in 6-OHDA-lesioned animals and protected glia cells. The extract significantly decreased striatal iNOS, COX-2, TNF-alpha and NF-kB immunostainings and, more importantly, HDAC immunostaining. All together, these data indicate the benefits of $M$. urundeuva for inflammation related pathologies and may stimulate translational studies focusing on its use for the prevention or treatment of neurodegenerative disorders as Parkinson's disease.
\end{abstract}

Keywords

Myracrodruon urundeuva, Inflammation, Neuroprotection, Polyphenols, Chalcones, Parkinson's disease

\section{Parkinson's Disease: The Neuroinflammation Involvement in this Neurological Disorder}

Affecting more than 7 million people worldwide [1], Parkinson's disease (PD) remains cureless, leading patients to death in approximately 16-years after the onset of symptoms [2]. In spite of the large number of possibilities in pharmacological and non-pharmacological treatments, these offer only symptomatic relieve to patients. Hence, the first effective therapeutic option available, Levodopa, remains the most effective one, despite not altering the natural history of the disease [3].

Although the refinement of the pharmacological treatment, achieved over the years, reflects a significant improvement in the quality of life of those affected by the pathology, research is focusing on efforts to the discovery of effective neuroprotective strategies against the PD's progression. PD is characterized by the loss of dopaminergic neurons and the presence of alpha-synuclein in the substantia nigra pars compacta (SNPc). Clinical and preclinical studies, as well, support a role of neuroinflammation in the PD pathophysiology, pointing to chronic neuroinflammation as one of the hallmarks of the diseasy [4,5]. Importantly, neuroinflammation is considered a target for neuroprotection actions [6], thus, neuroprotective agents, mainly those from natural sources, could be potential agents to be used for PD prevention and treatment.

*Corresponding author: Glauce Socorro de Barros Viana, Faculty of Medicine, Federal University of Ceará, Fortaleza, Rua Coronel Nunes de Melo, 1000 - Rodolfo Teófilo, Fortaleza - CE, Brazil, Postal code: 60430-275

Accepted: March 14, 2019

Published online: March 16, 2019

Citation: Viana GSB, Calou IBF (2019) Neuroprotective and AntiInflammatory Properties from the Bioactive Constituents of Myracrodruon Urundeuva, a Brazilian Medicinal Species. Transl Neurosci Res Rev 2(1):10-17 
Citation: Viana GSB, Calou IBF (2019) Neuroprotective and Anti-Inflammatory Properties from the Bioactive Constituents of Myracrodruon Urundeuva, a Brazilian Medicinal Species. Transl Neurosci Res Rev 2(1):10-17

Slowing down or even disrupting the processes that culminate in neuronal death, presuppose a reasonable understanding of these events. Furthermore, the lack of the necessary knowledge hampers the development of a rational neuroprotective therapy, which could be favored by the necessary comprehension of what triggers neurodegeneration. Nevertheless, the knowledge of some processes involved in neuronal death facilitates the planning of therapeutic strategies capable of delaying the disease evolution [7].

Among the targets for neuroprotective therapy, we can mention oxidative stress, mitochondrial dysfunction, excitotoxicity and neuroinflammation [8,9], the latter being much studied by investigators working on the neuroprotective actions of medicinal plants [10]. Phytochemicals are bioactive components of medicinal plants. They are usually secondary metabolites, known to prevent age associated declines in cognitive and motor functions, among others $[11,12]$ that are, at least partly, due to their antioxidant and anti-inflammatory properties.

Although some neuroprotective agents show promising effects in preclinical studies, they should be submitted to well designed clinical trials, in order to provide reliable translational data $[13,14]$. In this sense, several teams of investigators are working on potential neuroprotective treatments for PD, focusing on novel therapeutic targets, including drugs with antioxidant and anti-inflammatory actions [15]. The majority of neuroprotective agents are antioxidants and, many of them, bioactive components of medicinal plants [16].

Neuroprotective drugs should present the ability to reverse or prevent some of the damage leading to neuronal cell degeneration. Thus, neuroprotection refers to strategies and mechanisms that lead to a relative preservation of the neuronal integrity and to a reduction in the rate of neuronal loss over time. On the contrary, the neurotoxicity leading to neuronal injury may result in motor incoordination and cognitive dysfunction. Investigations of new neuroprotective drug development focus on mechanisms implicated in protein accumulation, oxidative stress, neuroinflammation and dopamine deficits in PD [17].

Acute neuroinflammatory processes, whether innate or adaptive, have a protective action in neuronal homeostasis; however, when becoming chronic, these processes trigger cascades that lead to neurodegeneration. Although it is not known whether neuroinflammation is a cause or a consequence of neuronal death, research, both in vitro and in vivo, has already shown the benefits of anti-inflammatory therapy in neural protection $[18,19]$, including the potential of medicinal plants as neuroprotection agents [20]. This perspective led us to study Myracrodruon urundeuva Fr. All. (Figure 1), a medicinal plant widely used in Northeastern region of Brazil, due its anti-inflammatory and healing actions.

\section{Myracrodruon Urundeuva: Neuroprotective Potential on PD}

The medicinal species $M$. urundeuva belongs to the Anacardiaceae family and is popularly known as "Aroeira-
do-Sertão". The ethnopharmacological study has initiated by the observation of the use of its stem bark for the treatment of gynecological diseases, such as cervicitis, due to its antiinflammatory properties. These actions were supported by clinical studies that resulted in a specific pharmaceutical preparation, available, in Brazil, for more than 25 years [21].

The success of this treatment guided preclinical studies, aiming at the knowledge of the medicinal properties, as well as the possible mechanisms of action involved in the pharmacological action of the plant. This initial pharmacological screening resulted in the discovery of peripheral antiallergic, anti-inflammatory, analgesic, antiulcer and antioxidant properties attributed to that medicinal plant [22-26]. Recently, we also observed by the first time the antidiabetic and hipolypidemic effects of the stem bark decoction from a cultivated specimen of $M$. urundeuva [27]. Furthermore, guided by the knowledge of the pathophysiological processes involved in $P D$, we decided to investigate whether the effects observed on the periphery would be reproduced at the level of the central nervous system.

We started the study by testing the neuroprotective activity of a fraction rich in chalcones, the major component of the plant extract. Chalcones are aromatic ketones and intermediates in flavonoid biosynthesis. They form a central core for a variety of important biological compounds and possess different activities, like antibacterial, antifungal, anti-inflammatory, antioxidant and antitumor, among others [28-30]. Chalcones are one of the largest classes of natural products, being studied with enthusiasm and already used in the medical clinic for the treatment of pain, gastric ulcer, liver

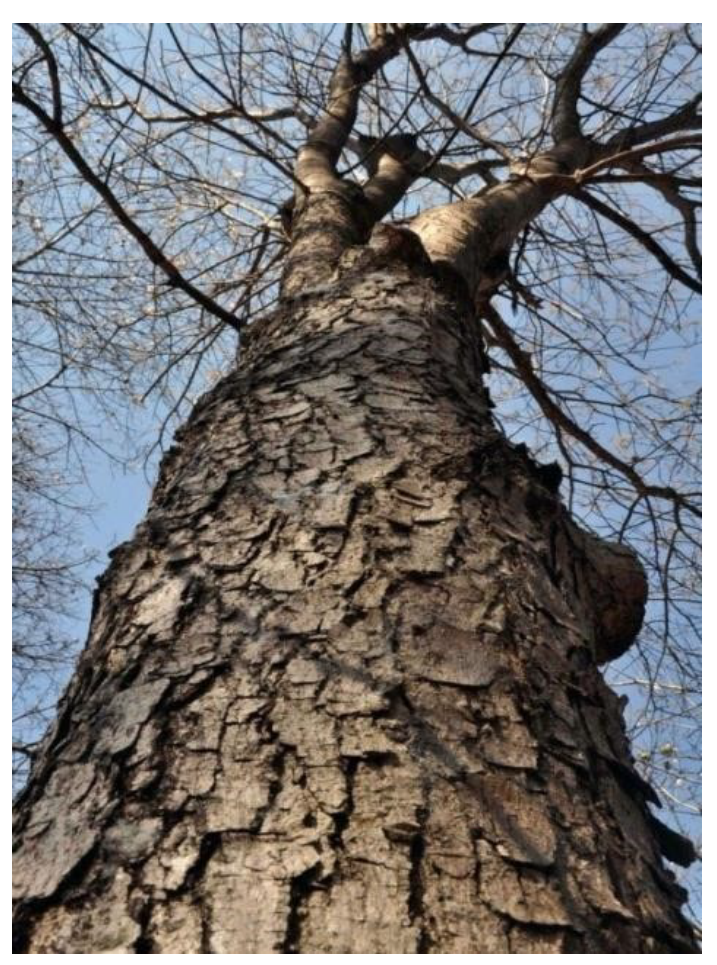

Figure 1: Myracrodroun urundeuva. The stem with its characteristic bark, source of several active principles responsible for the plant pharmacological actions. 

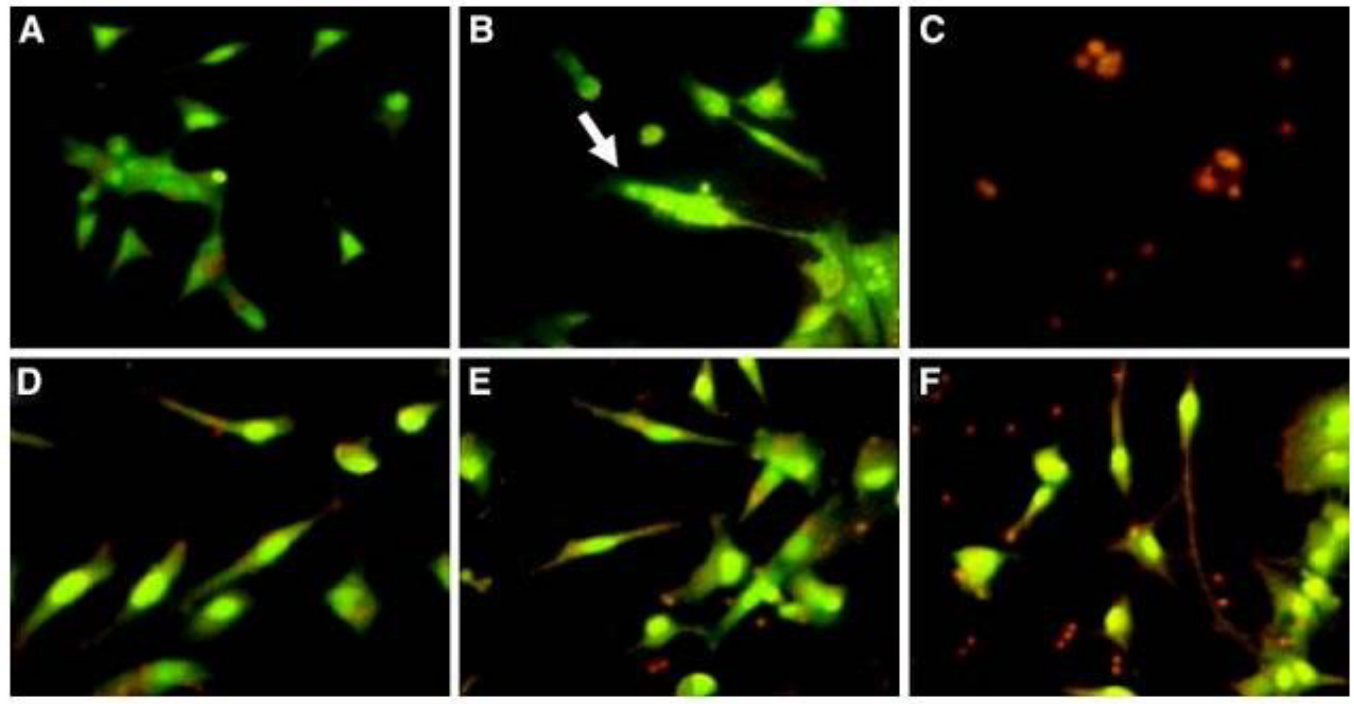

Figure 2: Apoptotic pattern of rat mesencephalic cells pre-incubated with $100 \mathrm{ng} / \mathrm{mL}$ CEF and exposed to 6-OHDA for $24 \mathrm{~h}$. Pathophysiological features of apoptosis and necrosis were observed after treatment with (b) 40 and (c) $200 \mu \mathrm{M}$ 6-OHDA, respectively. (a) Untreated cells, (d) CEF treated cells, (e) CEF treated cells $3 \mathrm{~h}$ before 6-OHDA exposure did not show apoptotic or (f) Necrotic characteristics. The cells were stained with acridine orange/ethidium bromide $(\times 400)$.<smiles>O=C(C1=Cc2cc(O)c(O)cc2C(c2ccc(O)cc2)C1C(=O)c1ccc(O)cc1O)c1ccc(O)cc1O</smiles><smiles>O=C(c1ccc(O)cc1O)c1cc2cc(O)c(O)cc2c(-c2ccc(O)cc2)c1C(=O)c1ccc(O)cc1O</smiles><smiles>O=C(C1=Cc2cc(O)c(O)cc2[C@]2(c3ccc(O)cc3)c3cc(O)cc(O)c3C(=O)[C@]12C(=O)O)c1ccc(O)c(O)c1O</smiles>

Figure 3: Urundeuvines A, B and C (from left to right). The polyhydroxylated structures of these chalcones are related to free radical scavenging, ensuring antioxidant activity to the compounds.

and heart problems [31-35].

Thus, the chalcone-enriched fraction (CEF) of the stem bark from $M$. urundeuva was tested in vitro in rat mesencephalic cells exposed to 6-hydroxydopamine (6OHDA). This neurotoxin causes dopaminergic degeneration by mechanisms related to mitochondrial dysfunction, specifically in the I and IV complexes, leading to oxidative stress and consequent neuronal death [36]. At concentrations ranging from 1 to $100 \mu \mathrm{g} / \mathrm{ml}, \mathrm{CEF}$ was able to increase the cell viability index, as determined by the 3-(4,5dimethylthiazol-2yl)-2,5-diphenyl tetrazolium test (MTT), in a concentrationdependent manner. The cell death was also evaluated by the fluorescence technique, using acridine orange and ethidium bromide (AO/EB) staining assays, observing the apoptotic pattern reversion in cells treated with CEF (Figure 2).

These results were corroborated by immunostaining for DAT, the dopamine transporter, and $\mathrm{TH}$, the tyrosine hydroxylase, this which is one the key enzymes in the catecholamine biosynthesis. CEF was able yet to decrease nitrite formation and to inhibit lipid peroxidation in mesencephalic cells, evidencing the antioxidant effect as one of the neuroprotection mechanisms $[37,38]$.

Three dimeric chalcones, denominated A, B and C urundeuvines, were isolated from the CEF (Figure 3). The arrangement of the hydroxyl groups found in the dimethyl chalcones is also related to their anti-inflammatory action, whose inhibition of 5-lipoxygenase is dependent upon the C-ring hydroxylation [39]. Whereas oxidative stress and neuroinflammation form a vicious cycle that amplifies the neurodegeneration process and adds to the indications of antioxidant and anti-inflammatory effects of the plant, we decided to carry out tests for evaluating whether the neuroprotective potential observed in the mesencephalic cell culture could be reproduced in vivo.

Thus, Wistar rats (weighing approximately $250 \mathrm{~g}$ ) previously anesthetized with ketamine $(80 \mathrm{mg} / \mathrm{kg}$, i.p.) and xylazine $(20 \mathrm{mg} / \mathrm{kg}$, i.p.) were submitted to stereotaxic surgery for the unilateral intrastriatal administration of 6-OHDA, according to a method previously described [40]. The drug, a standardized hydroalcoholic extract of Myracrodroun 
Citation: Viana GSB, Calou IBF (2019) Neuroprotective and Anti-Inflammatory Properties from the Bioactive Constituents of Myracrodruon Urundeuva, a Brazilian Medicinal Species. Transl Neurosci Res Rev 2(1):10-17

urundeuva (SEMU), at doses of 10,20 and $40 \mathrm{mg} / \mathrm{kg}$, was administered orally for 14 days, starting one hour before surgery.

At the end of treatment, the apomorphine-induced rotational behavior test was performed. Apomorphine is a dopaminergic agonist that, once administered to animals with unilateral striatal lesions, causes stereotyped rotational movements in the contralateral direction to the lesion. This test is widely used for evaluating the functional efficacy of the PD induction model, as well as to predict the possible neuroprotective action of drugs that can reduce the stereotypy of the animal [41].

The groups lesioned with 6-OHDA and treated with SEMU (20 or $40 \mathrm{mg} / \mathrm{kg}$, p.o.) decreased significantly, in a dosedependent manner, by 79 and $87 \%$, respectively, the number of contralateral rotations/h, relatively to the untreated 6-OHDA-lesioned group. The sham operated group did not present stereotyped rotations.

The presumable neuroprotective effect of SEMU was confirmed by the determination of dopamine (DA) levels, through high-performance liquid chromatography (HPLC). When compared to the injured animals, those treated with SEMU presented significantly higher levels of DA in the lesioned striata (Table 1).

The maintenance of DA levels is of primary importance for new pharmacological options in antiparkinsonian therapy, considering that the symptoms of the disease, as well as its evolution, are directly related to dopaminergic depletion in the nigrostriatal pathway. Through the histological technique of cresyl violet, the viability of the striatal neurons was possible to observe microscopically, with the finding of a large number of viable and preserved cells, approximately 2.1 times in the animals treated with SEMU $40 \mathrm{mg} / \mathrm{kg}$, when compared to those that did not receive the treatment. Immunostaining for $\mathrm{TH}$ was also performed and the results corroborate with those previously found, being possible to observe an increase of almost 13 times in enzyme labeling, in the animals receiving SEMU at its highest dose.

The extract standardization evidenced a large amount of phenolic compounds, presenting $13.3 \%$ of total polyphenols. These substances have been studied for their neuroprotective activity, after considering the anti-inflammatory and antioxidant actions of curcumin and green tea catechins on the central nervous system [42]. This scenario directed our research to the evaluation of the neuroprotection mechanism of action observed in SEMU, focusing on the nigrostriatal pathway inflammation established in the 6-OHDA model. Considering that the neuroinflammatory process is completely associated with mediators released by glia cells, we performed immunostaining for GFAP and OX-42, in order to verify the presence of astrocytes and activated microglia, respectively.

Microglia are more numerous in basal ganglia and substantia nigra, in rats, making these regions more susceptible to inflammatory aggressions, an important factor for success in establishing the model of parkinsonism $[43,44]$. Activated microglia and subsequent neuroinflammation have been consistently associated with PD and also identified in brain regions most affected by this disease $[45,46]$. Microglia have an important role in homeostasis and neural protection. When overactivated, as a result of injuries and immunological stimuli $[47,48]$, microglia become neurotoxic through mechanisms involving the excessive formation of free radicals and the increase in inflammatory mediators expression [49]. 6-OHDA is able to induce striatal microgliosis, from the second hour after the exposure to the cells, this effect persisting for weeks [50]. The extract, at the doses used, was able to inhibit microglia activation, relieving the process of neurodegeneration. Taking into account that the neurotoxicity caused by microglia activations is usually progressive, increasing and accelerating neuronal damage [51], agents capable of inhibiting or decreasing this activation are suitable for clinical trials, aimed at the discovery of new neuroprotective agents.

Table 1: Striatal levels of dopamine (DA) and DOPAC (ng/g tisuue).

\begin{tabular}{|c|c|c|}
\hline Experimental group & Dopamine & DOPAC \\
\hline $\begin{array}{l}\text { 6-OHDA } \\
\text { ipsilateral }\end{array}$ & $447.8 \pm 79.63^{a}$ & $752.3 \pm 201.1$ \\
\hline $\begin{array}{l}\text { 6-OHDA } \\
\text { contralateral }\end{array}$ & $2027 \pm 337.3$ & $713.9 \pm 16.63$ \\
\hline $\begin{array}{l}\text { SEMU } 10 \\
\text { ipsilateral }\end{array}$ & $1146 \pm 185.4$ & $990.3 \pm 417.4$ \\
\hline $\begin{array}{l}\text { SEMU } 10 \\
\text { contralateral }\end{array}$ & $1994 \pm 30.67$ & $333.8 \pm 46.78$ \\
\hline $\begin{array}{l}\text { SEMU } 20 \\
\text { ipsilateral }\end{array}$ & $1913 \pm 146.2$ & $2003 \pm 318.6^{a, b}$ \\
\hline $\begin{array}{l}\text { SEMU } 20 \\
\text { contralateral }\end{array}$ & $2072 \pm 588.3^{b}$ & $304.7 \pm 46.55$ \\
\hline $\begin{array}{l}\text { SEMU } 40 \\
\text { ipsilateral }\end{array}$ & $2450 \pm 163.7^{a, b}$ & $687.8 \pm 373.1^{\mathrm{a}}$ \\
\hline $\begin{array}{l}\text { SEMU } 40 \\
\text { contralateral }\end{array}$ & $3921 \pm 221.8$ & $1755 \pm 172.1$ \\
\hline $\begin{array}{l}\text { so } \\
\text { ipsilateral }\end{array}$ & $2668 \pm 350.4^{b}$ & $1985 \pm 182.4^{b}$ \\
\hline $\begin{array}{l}\text { So } \\
\text { Contralateral }\end{array}$ & $2986 \pm 519.3$ & $774.0 \pm 68.83$ \\
\hline
\end{tabular}

Myracrodruon urundeuva Hydroalcoholic Extract (SEMU 10, SEMU 20 and SEMU $40 \mathrm{mg} / \mathrm{kg}, \mathrm{p} . \mathrm{O}$ ) was administered daily for 14 days. The treatment started $30 \mathrm{~min}$ before and 1 hour after the unilateral 6-OHDA stereotaxic injection. Two weeks after the stereotaxic procedure, the animals were sacrificed by decaptation to remove both the right and left striata. The results were expressed as mean \pm SEM. Ipsilateral is the striatum of the side where 6-OHDA was injected (right lesioned-side) and contralateral is the striatum opposite to the lesion (left side).

6-OHDA group: Lesioned without treatment; SO group: Sham operated animals.

${ }^{a} p<0.05$ vs. contralateral control of the same group, ${ }^{b} p<0.05$ vs. 6-OHDA group (ipsilateral to injury) (ANOVA and Student-NewmanKeuls test).

6-OHDA: 6-hydroxydopamine; SO: Sham operated. 
Citation: Viana GSB, Calou IBF (2019) Neuroprotective and Anti-Inflammatory Properties from the Bioactive Constituents of Myracrodruon Urundeuva, a Brazilian Medicinal Species. Transl Neurosci Res Rev 2(1):10-17

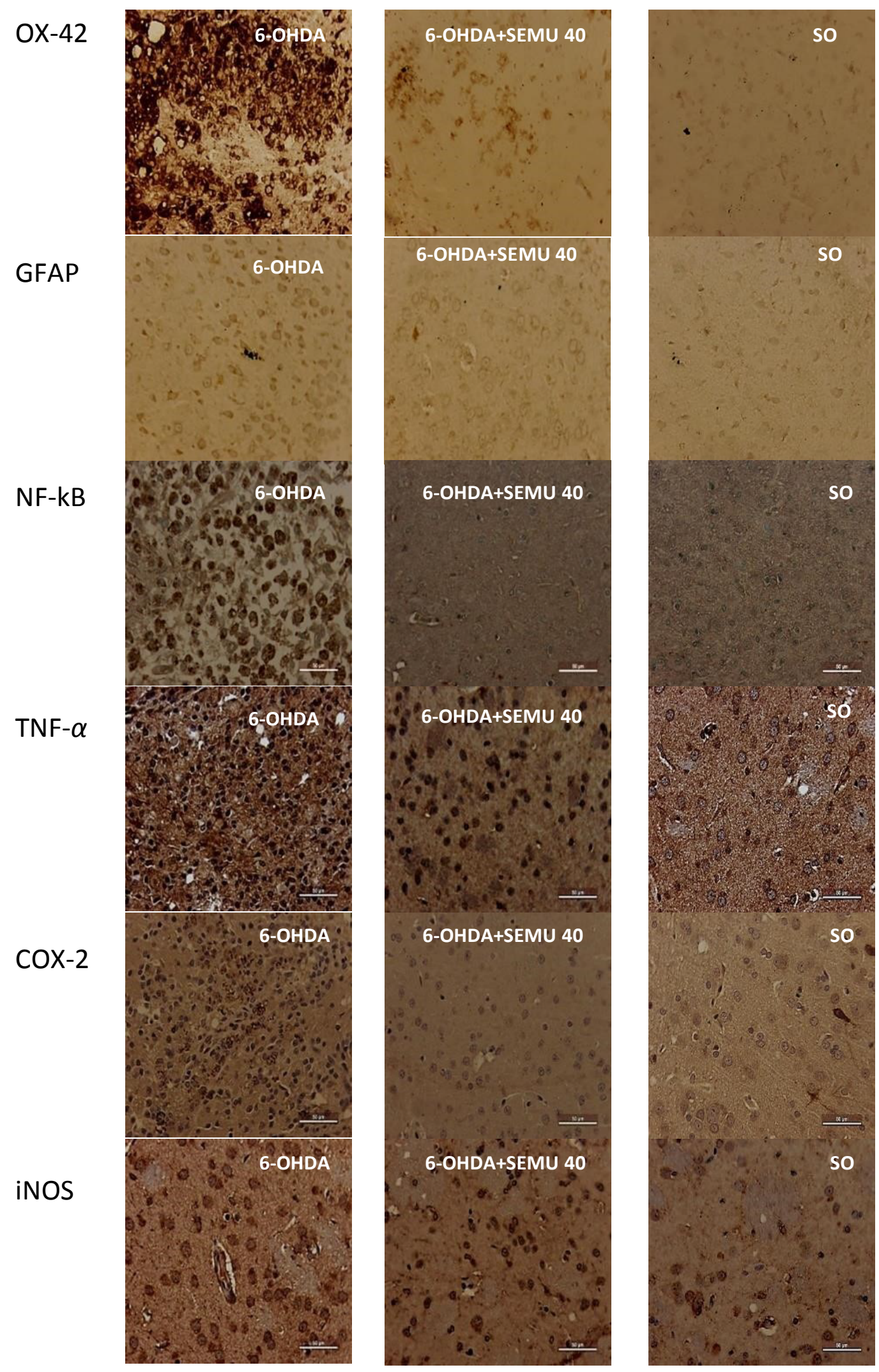

Figure 4: Effects of SEMU $(40 \mathrm{mg} / \mathrm{kg})$ on neuroinflammation indicators in striata from animals submitted to the unilateral 6-OHDA injury. The immunohistochemical labeling shows a significant decrease in neuroinflammation in the treated animals $(\times 400)$.

SEMU: Myracrodruon urundeuva Hydroalcoholic Extract; 6-OHDA: Hydroxydopamine; SO: Sham operated.

The means by which microgliosis improves neurodegeneration consist of the release of proinflammatory mediators, such as TNF-alpha, IL-1B, NO, and COX-2, which amplify the neuroinflammation/oxidative stress cascade, by accelerating the neurodegenerative process [52]. The striatal analysis revealed that the animals treated with SEMU presented marked 
Citation: Viana GSB, Calou IBF (2019) Neuroprotective and Anti-Inflammatory Properties from the Bioactive Constituents of Myracrodruon Urundeuva, a Brazilian Medicinal Species. Transl Neurosci Res Rev 2(1):10-17

reduction of the neuroinflammatory process. The immunostainings for mediators, such as TNF-alpha, COX-2 and iNOS, in addition to the NF-kB transcription factor (Figure 4), were shown to be much more tenuous in the striatum of animals treated with the extract of $M$. urundeuva, proving its central anti-inflammatory action [53].

Nevertheless, NF-kB, known as the major transcriptional factor of a wide range of cytokines, shows its pathway activation much more pronounced in patients with PD. Furthermore, NF-kB is an important target in the reduction of neuroinflammation and oxidative stress. The inhibition of microglia activation associated with the reduction of NF$\mathrm{kB}$ activation are probably the main factors responsible for plant-mediated neuroprotection [54]. In additional tests, we have shown that the same extract is able to inhibit the brain histone deacetylases (HDACs), which are involved with epigenetic mechanisms and activation of neuronal survival genes, promoting the protection of dopaminergic neurons in PD [55].

Chalcones are one of the bioactive components present in $M$. urundeuva extracts and responsible for some of the biological activities of this plant. In addition, chalcone derivatives were shown to be neuroprotective, through the downregulation of tau protein phosphorylation and insoluble $A \beta$ peptide formation, involved with the pathogenesis of Alzheimer's disease, a neurodegenerative disease as PD [56]. Furthermore, HDACs inhibitors have been shown to be neuroprotective, both in vitro (astrocyte assays) and in vivo models (rat traumatic brain injury and brain ischemia models) $[57,58]$.

\section{Conclusion}

Taking together, all these findings indicate that SEMU appears to be a promising agent of natural origin for protection against PD and neurodegeneration. Neuroinflammatory events are known to be present in neurodegenerative diseases, including PD. They are involved with the dopaminergic neuronal loss and constitute a potential target for neuroprotection. However, it is not known whether neuroinflammation is the primary cause of neurodegeneration, but certainly its presence may contribute to the continued loss of dopaminergic neurons [59]. There are, however, still unanswered questions related to the concentrations of phytochemicals able to cross the blood brain barrier, as well as their quality, that could interfere with the final results [60]. Despite of all these problems, translational studies dealing with anti-inflammatory medicinal plants as $M$. urundeuva and its bioactive components should be highly stimulated and could focus on their use for the prevention and treatment of neurodegenerative diseases as PD.

\section{Conflict of Interest}

The authors declare no potential conflict of interest with respect to research, authorship and/or publication of this manuscript.

\section{Copyright and Permission Statement}

To the best of my/our knowledge, the materials included in this chapter do not violate copyright laws. All original sources have been appropriately acknowledged and/or referenced. Where relevant, appropriate permissions have been obtained from the original copyright holder(s).

\section{References}

1. Statistics on Parkinson's. Parkinson's Disease Foundation.

2. Forsaa EB, Larsen JP, Wentzel-Larsen T, et al. (2010) What predicts mortality in Parkinson disease: A prospective population-based long-term study. Neurology 75: 1270-1276.

3. Tahtis V, Kaski D (2017) Parkinson's disease treatments: Focus on transcranial direct current stimulation (tDCS). Journal of Parkinsonism and Restless Legs Syndrome 7: 55-70.

4. Hirsch EC, Vyas S, Hunot S (2012) Neuroinflammation in Parkinson's disease. Parkinsonism Relat Disord 18: S210-S212.

5. Wang Q, Liu Y, Zhou J (2015) Neuroinflammation in Parkinson's disease and its potential as therapeutic target. Transl Neurodegener 4: 19.

6. Hirsch EX, Hunot S (2009) Neuroinflammation in Parkinson's disease: A target for neuroprotection. Lancet Neurol 8: 382-397.

7. Schapira AH, Olanow CW, Greenamyre JT, et al. (2014) Slowing of neurodegeneration in Parkinson's disease and Huntington's disease: Future therapeutic perspectives. Lancet 384: 545-555.

8. Wirdefeldt K, Adami H-O, Cole P, et al. (2011) Epidemiology and etioloy of Parkinson's disease: A review of the evidence. Eur J Epidemiol 26: S1-S58.

9. Ottolini D, Calì T, Brini M (2013) Etiology and pathogenesis of Parkinson's disease: Role of mitochondrial pathology. Research and Reports in Biochemistry 3: 55-70.

10. Kure C, Timmer J, Stough C (2017) The immunomodulatory effects of plant extracts and plant secondary metabolites on chronic neuroinflammation and cognitive aging: A mechanistic and empirical review. Front Pharmacol 8: 117.

11. Kumar GP, Khanum F (2012) Neuroprotective potencial of phytochemicals. Pharmacogn Rev 6: 81-90.

12. Naoi M, Inaba-Hasegawa K, Shamoto-Nagai M, et al. (2017) Neurotrophic function of phytochemicals for neuroprotection in aging and neurodegenerative disorders: Modulation of intracellular signaling and gene expression. J Neural Transm (Vienna) 124: 1515-1527.

13. Douna H, Bavelaar BM, Pellikaan H, et al. (2012) Neuroprotection in Parkinson's disease: A systematic review of the preclinical data. The Open Pharmacology Journal 6: 12-26.

14. Sarkar S, Raymick J, Imam S (2016) Neuroprotective and therapeutic strategies against Parkinson's disease: Recent perspectives. Int J Mol Sci 17: 904.

15. Kim KS (2017) Toward neuroprotective treatments of Parkinson's disease. Proc Natl Acad Sci U S A 114: 3795-3797.

16. Levi MS, Brimble MA (2004) A review of neuroprotective agents. Curr Med Chem 11: 2383-2397.

17. Elufioye TO, Berida TI, Habtemariam S (2017) Plants-derived neuroprotective agents: Cutting the cycle of cell death through multiple mechanisms. Evidence-Based Complementary and Alternative Medicine 2017.

18. Tansey MG, Goldberg MS (2010) Neuroinflammation in Parkinson's disease: Its role in neuronal death and implications for therapeutic intervention. Neurobiol Dis 3: 510-518. 
Citation: Viana GSB, Calou IBF (2019) Neuroprotective and Anti-Inflammatory Properties from the Bioactive Constituents of Myracrodruon Urundeuva, a Brazilian Medicinal Species. Transl Neurosci Res Rev 2(1):10-17

19. Naeem S, Ikram R, Khan SS, et al. (2017) NSAIDs ameliorate cognitive and motor impairment in a model of parkinsonism induced by chlorpromazine. Pak J Pharm Sci 30: 801-808.

20. Costa IM, Cavalcanti JRLP, Queiroz D, et al. (2017) Supplementation with herbal extracts to promote behavioral and neuroprotective effects in experimental models of Parkinson's disease: A systematic review. Phytother Res 31: 959-970.

21. Campos ACS (2008) Study about the use of Brazilian peppertree's vaginal cream (Myracrodruon urundeuva All.) in patients attended in a Gynecology Infirmary of a Basic Health Unit in Fortaleza. Fed Univ Ceará.

22. Viana GS, Bandeira MA, Matos FJ (2003) Analgesic and antiinflammatory effects of chalcones isolated from Myracrodruon urundeuva Allemão. Phytomedicine 10: 189-195.

23. Albuquerque RJM, Leal LKAM, Bandeira MAM, et al. (2011) Chalcones from Myracrodruon urundeuva are efficacious in guinea pig ovalbumin-induced allergic conjunctivitis. Rev Bras Farmacog 21: 124-129.

24. Souza SM, Aquino LCM, Milach-Junior AC, et al. (2007) Antiinflammatory and antiulcer properties of tannins from Myracrodruon urundeuva Allemão (Anacardiaceae) in rodents. Phytother Res 21: 220-225.

25. Rodrigues LV, Ferreira FV, Regadas FSP, etal. (2002) Morphological and morphometric analyses of acetic acid-induced colitis in rats after treatment with enemas from Myracrodruon urundeuva $\mathrm{Fr}$. All.(Aroeira-do-sertão). Phytother Res 16: 267-272.

26. Viana GSB, Souza-Filho MVP, Moura LC, et al. (1997) Analgesic and anti-inflammatory effects of the tannin fraction from the bark of Myracrodruon urundeuva, Fr. All. Phytother Res 11: 118122.

27. Moreira CA, Moreira IC, Alves VJ, et al. (2018) The medicinal species Myracrodruon urundeuva Fr. All. presents antidiabetic and hypolipidemic properties, probably related to its antioxidant and antiinflammatory actions. Global J Med Plants 4: 342-351.

28. Maydt D, De Spirt S, Muschelknautz C, et al. (2013) Chemical reactivity and biological activity of chalcones and other $\alpha, \beta$ unsaturated carbonyl compounds. Xenobiotica 43: 711-718.

29. Singh P, Anand A, Kumar V (2014) Recent developments in biological activities of chalcones: A mini review. European Journal of Medicinal Chemistry 85: 758-777.

30. Rozmer Z, Perjési P (2016) Naturally occurring chalcones and their biological activities. Phytochemistry Reviews 15: 87-120.

31. Nobre-Junior HV, Damasceno FM, Oliveira Ra, et al. (2007) Neuroprotective actions of tannins from Myracrodruon urundeuva on 6-hydroxydopamine-induced neuronal cell death. Journal of Herbs, Spices \& Medicinal Plants 13: 30-35.

32. Ni L, Meng CQ, Sikorski JA (2004) Recent advances in therapeutic chalcones. Expert Opinion on Therapeutic Patents 14: 16691691.

33. Kang DG, Lee AS, Mun YJ, et al. (2004) Butein ameliorates renal concentrating ability in cisplatininduced acute renal failure in rats. Biol Pharm Bull 27: 366-370.

34. Isomoto H, Furusu $H$, Ohnita $K$, et al. (2005) Sofalcone, a mucoprotective agent, increases the cure rate of Helicobacter pylori infection when combined with rabeprazole, amoxicillin and clarithromycin. World J Gastroenterol 11: 1629-1633.

35. Lee YS, Lim SS, Shin KH, et al. (2006) Antiangiogenic and anti- tumor activities of 2'-hydroxy-4'methoxychalcone. Biol Pharm Bull 29: 1028-1032.

36. Jeon BS, Jackson-Lewis V, Burke RE (1995) 6-Hydroxydopamine lesion of the rat substantia nigra: Time course and morphology of cell death. Neurodegeneration 4: 131-137.

37. Rice-Evans CA, Nicholas J, Miller NJ, et al. (1996) Structureantioxidant activity relationships of flavonoids and phenolic acids. Free Radic Biol Med 20: 933-956.

38. Nobre-Junior HV, Oliveira RA, Maia FD, et al. (2009) Neuroprotective effects of chalcones from Myracrodruon urundeuva on 6-hydroxydopamine-induced cytotoxicity in rat mesencephalic cells. Neurochem Res 34: 1066-1075.

39. Sogawa S, Nihro Y, Ueda H, et al. (1993) 3,4-Dihydroxychalcones as potent 5-lipoxygenase and cyclooxygenase inhibitors. J Med Chem 36: 3904-3909.

40. Calou I, Bandeira MA, Aguiar-Galvão W, et al. (2014) Neuroprotective properties of a standardized extract from Myracrodruon urundeuva Fr. All. (Aroeira-Do-Sertão), as evaluated by a Parkinson's disease model in rats. Parkinsons Dis 2014.

41. Mandel RJ (2000) Effect of acute L-dopa pretreatment on apomorphine-induced rotational behavior in a rat model of Parkinson's disease. Exp Neurol 61: 212-219.

42. Silva RFM, Pogačnik L (2017) Food, polyphenols and neuroprotection. Neural Regen Res 12: 582-583.

43. Akiyama H, L McGeer P (1989) Microglial response to 6-hydroxydopamine induced substantia nigra lesions. Brain Res 489: $247-253$.

44. Lawson U, Perry VH, Dri P (1990) Heterogeneity in the distribution and morphology of microglia in the normal adult mouse brain. Neuroscience 39: 151-170.

45. Richardson JR, Hossain MM (2013) Microglial ion channels as potential targets for neuroprotection in Parkinson's disease. Neural Plast 2013.

46. Skaper SD (2007) The brain as a target for inflammatory processes and neuroprotective strategies. Ann N Y Acad Sci 1122: 23-34.

47. Nimmerjahn A, Kirchhoff F, Helmchen F (2005) Resting microglial cells are highly dynamic surveillants of brain parenchyma in vivo. Science 308: 1314-1318.

48. Town T, Nikolic V, Tan J (2005) The microglial 'activation' continuum: From innate to adaptive responses. J Neuroinflammation 2: 24.

49. Block ML, Zecc L, Hong J (2007) Microglia-mediated neurotoxicity: Uncovering the molecular mechanisms. Nat Rev Neurosci 8: 57-69.

50. Mulas G, Espa E, Fenu S, et al. (2016) Differential induction of dyskinesia and neuroinflammation by pulsatile versus continuous I-DOPA delivery in the 6-OHDA model of Parkinson's disease. Exp Neurol 286: 83-92.

51. Teismann P, Tieu K, Cohen O, et al. (2003) Pathogenic role of glial cells in Parkinson's disease. Mov Disord 18: 121-129.

52. Cai Z, Hussain MD, Yan L (2014) Microglia, neuroinflammation, and beta-amyloid protein in Alzheimer's disease. Int J Neurosci 124: 307-321.

53. Shih RH, Wang CY, Yang CM (2015) NF-kappaB signaling pathways in neurological inflammation: A mini review. Front Mol Neurosci 8: 77. 
54. Viana GS, Calou IB, Xavier CC, et al. (2017) The neuroprotective and anti-inflammatory effects of Myracrodruon urundeuva are related to inhibitions of brain inflammatory enzymes, cytokines and HDAC. Journal of Pharmacology and Medicinal Chemistry 1: 15-22.

55. Jin H, Kanthasamy A, Harischandra DS, et al. (2014) Histone hyperacetylation up-regulates protein kinase $c \delta$ in dopaminergic neurons to induce cell death: Relevance to epigenetic mechanisms of neurodegeneration in Parkinson disease. J Biol Chem 289: 34743-34767.

56. Jeon KH, Lee E, Jun KY, et al. (2016) Neuroprotective effect of synthetic chalcone derivatives as competitive dual inhibitors against $\mu$-calpain and cathepsin $B$ through the downregulation of tau phosphorylation and insoluble $A \beta$ peptide formation. Eur J Med Chem 121: 433-444.
57. Lu J, Frerich JM, Turtzo LC, et al. (2013) Histone deacetylase inhibitors are neurop' rotective and preserve NGF-mediated cell survival following traumatic brain injury. Proc Natl Acad Sci U S A 110: 10747-10752.

58. Ziemka-Nalecz M, Zalewska T (2014) Neuroprotective effects of histone deacetylase inhibitors in brain ischemia. Acta Neurobiol Exp (Wars) 74: 383-395.

59. Gilgun-Sherki Y, Melamed E, Offen D (2006) Anti-inflammatory drugs in the treatment of neurodegenerative diseases: Current state. Ann Pharm Des 12: 3509-3519.

60. Davinelli S, Maes M, Corbi G, et al. (2016) Dietary phytochemicals and neuroinflammation: From mechanistic insights to translational challenges. Immun Ageing 13: 16. 